\title{
Review on College Students' Ideological and Political Education from the Psychological Perspective
}

\author{
Guangming $\mathrm{He}^{1,2}$, Limin Yao ${ }^{1}$ \\ ${ }^{1}$ Hunan University, Changsha, Hunan, 410082 \\ ${ }^{2}$ Changsha Medical University, Changsha, Hunan, 410219
}

Keywords: college students' ideological and political education; psychological perspective; review

\begin{abstract}
According to the category of subject theory, scholars use psychological theory to study the ideological and political education of college students, which mainly involve positive psychology, humanistic psychology, social psychology, constructivism psychology, and moral developmental psychology. Although some researches have achieved certain results, there are some limitations and shortcomings, which are embodied in the fact that the psychological theory and the ideological and political education are not well-matched, the research perspective is lacking in overall vision, and the research methods need further innovation.
\end{abstract}

\section{Introduction}

With the promulgating of the "Opinions on Further Strengthening and Improving Ideological and Political Education for College and University students" of the CPC Central Committee in 2004, the research on ideological and political education of college and university students has entered a new stage and has become a hot topic in academic circles. In this context, different scholars used different theories to study the ideological and political education of college and university students from the perspective of different disciplines, in order to achieve the purpose of continuously improving the validity of the ideological and political education of college and university students. Through studying the existing literature, it is found that there is relatively little research on the ideological and political education of college and university students from the perspective of psychology. It is not difficult to find that the research on ideological and political education using psychological theory mainly involves basic elements of ideological and political education such as educators, educational methods, education processes, and education environment. If we examine from the nature of the discipline, the research on ideological and political education of college and university students under the perspective of psychology is mainly reflected in positive psychology, humanistic psychology, social psychology, constructivism psychology, moral developmental psychology, etc. Following, the author will comment on them.

\section{Positive Psychology and Ideological and Political Education for College Students}

Xie Yun and Ruan Guodong [1] pointed out that positive psychology has changed the "passive response" of students' ideological and political education to the problem-solving model of students, improved the relationship between subject and object of ideological and political education in colleges and universities, and expanded the connotation and approach of ideological and political education in colleges and universities. Prof. Liu Liquan and Xiao Dongmei [2] pointed out that ideological and political education should "expect to light hope, gain happiness and delight”. Zeng Changqiu and Fan Xin[3] have conducted a rational analysis of the application of positive psychology in ideological and political education in colleges and universities, and on this basis, put forward the application of positive psychology in ideological and political education in colleges and universities: seize the opportunity-Conduct active thought leadership and psychological counseling, and wait and see - change the ability of self-analysis of educational objects, supervise feedback optimize the process of changes in educational objects. Wu Di and Dai Rui [4] pointed out that the 
theory of positive psychology establishes the "mental-social" operating mechanism for self-education, emphasizing that self-consciousness is the psychological mechanism for self-education, but it needs to operate in an active institution or organization system. Education should aim at the shaping of positive personality, and the perfection of the process should be achieved through active education in an active education environment. Cong Jianwei [5] believes that positive psychology is closely related to subjectivity, acceptability, daily life, innovation, and effectiveness of ideological and political education. Therefore, improving the effectiveness of ideological and political education should strengthen positive emotional experience, enhance the cultivation of positive personality and reinforce the creation of a positive environment.

\section{Humanistic Psychology and Ideological and Political Education for College Students}

Huang Xiting [6] combined the characteristics of Chinese college and university students, and classified the needs of the students through surveys. The needs of college and university students were divided into six categories and eighteen dimensions. The six categories in the category of needs were physiological need, security need, communication need, requirement for respecting and contributing. Eighteen dimensions refer to survival, material enjoyment, sex, order, avoiding harm, avoiding shame, friendship, seeking help, belonging, achievement, self-respect, independence, power, knowledge, seeking beauty, developing physical strength, and helping others, contribution, risk. Zhang Ping and Zhang Ting [7] analyzed the needs of college and university students using Maslow's hierarchy of needs. They believe that the physiological need of students is mainly the needs of physical and mental health, manifested as medical and health epidemic prevention, and mental health status, love, marriage; the security need is mainly for the needs of a safe and stable living environment, manifested as campus stability, dormitory security, and harmonious teaching environment; the social need is mainly the need to integrate into formal or informal organizations, manifested as integrating into the class environment, Participating in the caucus organizations, joining student organizations, cherishing the fellowship, and religious beliefs; the need for respect mainly refers to the pressure on self-esteem in the face of difficulties, manifested as economic pressure, learning pressure, interpersonal pressure, psychological pressure, employment pressure; The need for self-realization mainly refers to the demonstration of the overall quality of the moral, intellectual, and physical quality. It is manifested in political pursuits, learning and research capabilities, cultural and practical activities, organizational management capabilities, and professional developmental capabilities. Their analysis of the characteristics of students' needs laid a good foundation for improving the effectiveness of college and university students' ideological and political education. Zhang Shizhan [8] used literature and questionnaire methods to fully understand the needs of college and university students and the actual status of their ideological and political education. He drew lessons from the research results of psychology and pedagogy, which there were three reasons in the status quo of education and the current situation of the lack of effectiveness of ideological and political education for college and university students. At same time, Zhang proposed the countermeasures for improving the effectiveness of ideological and political education.

\section{Social Psychology and Ideological and Political Education for College Students}

$\mathrm{Hu}$ Yu of Liaoning Normal University [9] demonstrated the agreement between attitude theory and the effectiveness of the ideological and political education of college and university students in the "Study on the effectiveness of undergraduates' ideological and political education from the perspective of attitude theory", and analyzed the effectiveness of undergraduates' ideological and political education from the perspective of attitude theory. In the paper, he explored the reasons of missing effectiveness, and put forward the countermeasures to enhance the effectiveness of college and university students' ideological and political education from the perspective of attitude theory. Wu Leiming [10] pointed out that the change in the attitude of ideological and political education objects is an important part of ideological and political education activities in his research. The 
basic factors that affect the attitudes of educated people include ideological and political educators, educational information, educational objects, and educational situations. The internal mechanism of attitude change of the educatees is the coordinating the balance of cognitive structure. Luo Yali[11] simplified the model of ideological and political education based on the "perception model" by Hovland and Janis.The model consists of four parts: the main body of ideological and political education, the method of ideological and political education,the object of ideological and political education,the situation of ideological and political education. In this case, she imagined that the attitude changes that took place in ideological and political education subjects involved the following four factors: the subject of ideological and political education, the methods of ideological and political education, the object of ideological and political education itself, and the situation of ideological and political education.

\section{Constructivism and Ideological and Political Education for College Students}

Chen Changxing and Du Caiping[12] found by studying that constructivism makes up for the disadvantages of traditional inculcation education in talent cultivation. It had many advantages in promoting the development of students' critical thinking, creative thinking and cultivating innovative talents. The view of knowledge, learning and teachers in constructivism has opened up new ideas for training innovative talents. Heng Yang and Liu Xiaowu [13] pointed out that constructivism psychology theory has an important guiding role in improving the effectiveness of ideological and political education for college university students. The guiding role is embodied in that establishing students' subject status, actively developing students' self-education, introducing peer education to build a collaborative model and carrying out situational education activities on the basis of problems. Tao Ran [14] believes that improving the effectiveness of ideological and political education based on the theory of constructivism can be instructed from the perspective of double construction, effective dialogue, and attention to experience. Ye Xianghong [15] believes that the constructivism learning theory provides a theoretical basis for the effectiveness of ideological and political education. It is necessary to adhere to knowledge relativism of the ideological and political education to improve the effectiveness of ideological and political education. At the same time, the educators ought to adhere to the view of which students are prepared and thoughtful in ideological and political education, and of which learning is the generation and construction of meaning. These are conducive to learners internalizing and practicing the content of ideological and political education as well as to exerting subjectivity. The discussion above is not difficult to find that constructivism psychology provides a new perspective for the objectives orientation of the ideological and political education of college and university students, the educational methods choice, the reconstruction of the educational environment. Constructivism psychology also provides a new idea for the effectiveness improvement of the ideological and political education.

\section{Moral Developmental Psychology and Ideological and Political Education for College Students}

Liu Chunqiong [16] believes that the individual's different cognitive levels of moral rules, moral identities, moral responsibility dispersion and obedience psychology will lead to various psychological alienation of knowledge and practice, and thus draw the irrationality of moral knowledge and compliance as moral education goals, and It points out the possible countermeasures--dissolving the investigation of whether moral knowledge is consistent or not, and turning to a systematic analysis approach, which is also an important way to improve the effectiveness of moral education. Hua Lingzhi [17] believes that promoting students' ideological and moral development is an important task of ideological and moral education according to the theory of moral developmental psychology. So the effectiveness of ideological and moral education should comply with the law of moral development, which the educators ought to change the concept of ideological and moral education, ideological and moral education should be in line with the 
student's age characteristics, and the educational methods are supposed to transform from teaching the students how to accept to teaching how to select.Through the intervention of the students, $\mathrm{Li}$ Weiqiang and Guo Benyu[18] discovered that the students' awareness level for the educational institution moral atmosphere has been improved to varying degrees, and their moral judgment ability has been significantly improved. This reveals that promoting the effectiveness of moral education can begin with improving students' moral cognition.Lin Hailiang and Dong Biao [19] pointed out that moral need is the direct motive force for the development of students' morality, the moral conflict between the true, the good, the beauty and the fake, the hideous, the evil is the fundamental driving force for student moral development in the dynamic system of students' moral development.Moral education is necessary for promoting the development of the contradiction between the true, the good, the good, the false and the evil and cultivating students' rational understanding of morality to improve the pertinence and effectiveness of moral education based on the law of physical and mental development and studying and satisfying the moral needs of the students.Liu Xinfen [20] believes that it is necessary improving the effectiveness of college and university students' ideological and moral education and promoting the moral development of College and university students in terms of ethics, moral values, and social environment in addition to stimulating the internal kinetic energy of the students.

\section{Conclusion}

Based on the above-mentioned literature, it is learned that researchers have used psychology-related theories to do a lot of useful explorations on the ideological and political education of college and university students and they have produced a lot of theoretical significance and practical value research results which promotes the development of ideological and political education. But there are some limitations and deficiencies in the research.

(1) The corresponding between the college and university students' ideological and political education and psychology is low. The researches fail to form a systematic theoretical framework.

The logic of the college and university students' ideological and political education from the perspective of psychology ought to be based on the perspective of psychology to improve the effectiveness and scientificity of ideological and political education by studying systematically the goals, content, methods, influencing factors, educational processes and laws of psychology and ideological and political education, and the educators quality, psychological quality and working ability, the educatees physical and mental characteristics, needs, the relationship and law of knowing, feeling,will and behavior.However, existing research shows that the use of psychological theory to study ideological and political education is more focused on the concept transplantation and the methods mechanical application. The corresponding between the college and university students' ideological and moral education and psychology is low. The researches fail to form a systematic theoretical framework.

(2) The research perspective for the college and university students' ideological and political education is single, which fails to construct an overall macro research perspective.

Existing researches mainly involve positive psychology, humanistic psychology, social psychology, constructivism psychology and moral developmental psychology. They are limited to exploring one or more of the factors of ideological and political education, such as the process factors, the subject and object factors, the mediator factors and the environment factors instead of analyzing, summarizing and inducing the whole process and all factors of ideological and political education such as the diversified goals of ideological and political education, the individual differences of ideological and political education objects and the rich educational contents, etc. ,which lead to the research results lacking a holistic view.

(3) The research methods for the college and university students' ideological and political education are outdated, and less empirical research methods are adopted in the existing researches.

Most of the existing researches adopt the deductive and inductive methods to analyze literature data. Rational speculation and empirical research play an important role. They rarely track research results and research objects. There are few empirical research methods in the studying.There is a 
phenomenon of lacking of observing, experimenting and comparing for the educatees.It is undeniable that the rational speculating and empirical research reveal some of the laws and characteristics of the research object to a certain extent. However, reliance on the two research methods too much will be bound to lead to the phenomena of incomplete generalization for the essential characteristics of the research object and failing to fully grasp its fundamental laws. It is necessary to innovate the research methods facing the complex and changeable ideological and political education environment and the ideological and psychological state of the educational objects.

\section{References}

[1] Xie Yun, Zhai Guodong. The application and thinking of positive psychological theory in ideological education in universities [J]. Educational Exploration, 2013(4):104-105

[2] Liu Liquan, Xiao Dongmei. Positive, Hope, Happiness, and Happiness: Enlightenment of Positive Psychology on Ideological and Political Education of University Students [J]. Academic Forum, 2009 (7):171-175

[3] Zeng Changqiu, Fan Xin. Positive Psychology and Ideological and Political Education in Colleges and Universities [J]. Journal of Henan Normal University (Philosophy and Social), 2015(1): 185-188

[4] Wu Di, Dai Rui. Objective orientation and process optimization of self-education from the perspective of positive psychology $[\mathrm{J}]$. School Party Building and Ideological Education, 2014(6):19-21

[5] Cong Jianwei. Research on the Actual Effect of Ideological and Political Education from the Perspective of Positive Psychology[J]. Journal of Ideological Education Research, 2014(9): 79-82

[6] Huang Xiting. Investigation of College Students' Need Structure in China [J]. Psychological Science Communication, 1988(10): 32-33

[7] Yu Ping, Zhang Ting. A Brief Discussion on the Inspiration of Maslow's Hierarchy of Needs Theory to the Innovation of College Students' Ideological and Political Education Workflow[J]. School Party Building and Ideological Education, 2011(6): 46-47

[8] Zhang Shizhan. Analysis of the effectiveness of college students' ideological and political education based on the theoretical perspective[D]. Ocean University Master’s Thesis, 2012: 5.

[9] Hu Yu. Research on the effectiveness of undergraduates' ideological and political education in the perspective of attitude theory [D]. Master thesis of Liaoning Normal University, 2010: 5

[10] Wu Leiming. The Application of Attitude Change Theory in Ideological and Political Education in Colleges and Universities [J]. Journal of Ideological \& Theoretical Education, 2010(9): 95-97

[11] Luo Yali. Influencing Factors of the Effectiveness of Ideological and Political Education: A Social Psychoanalysis[J]. Jianghan Forum, 2010(2): 30-33

[12] Chen Changxing, Du Caiping. Ideological and political education in colleges and universities and the cultivation of innovative talents-An analysis based on the perspective of constructivism[J]. Hubei Social Sciences, 2012, 11(11): 190-192

[13] Heng Yang, Liu Xiaowu. Practical Exploration of Ideological and Political Education Based on Constructivism Theory[J]. China Adult Education, 2011(6): 111-112

[14] Tao Ran. An Analysis of the New Context of Ideological and Political Education from the Perspective of Constructivism [J]. Jiangsu Social Sciences, 2012(1): 55-57

[15]YE Xianghong. On the Ideological and Political Education in the View of Constructivism[J]. 
Journal of Central South University (Social Science Edition),2013(2):189-193

[16] Liu Chunqiong. On the irrationality of moral knowledge and practice as moral education goals [J]. Shanghai Research in Education, 2013(4): 38-40

[17] Hua Lingzhi. Analysis of mistakes and adjustments in the development of students' ideological and moral development in political classes in middle schools[J]. Contemporary Educational Science, 2011(18):54-58

[18] Li Weiqiang, Guo Benzheng. Educational Intervention Experiment of the Effect of School Moral Consciousness on Moral Development[J]. Psychological Science, 2013(2):390-394

[19] Lin Hailiang, Dong Biao. New theory of students' moral development motivation[J]. Educational Science Research, 2013(12): 61-65

[20] Liu Xinfen. Several new approaches to college students' moral development [J]. Jiangsu Higher Education, 2008(2): 117-118

About the authors:

Guangming He (1975-), Leiyang Hunan, Ph.D. of Hunan University and Deputy Director of Scientific Research Department in Changsha Medical University, Associate Professor. Research Field: The effectiveness of Ideological and Political Education, Psychology of management in Colleges and Universities.

Limin Yao (1960- ), Anxiang, Hunan, Vice President of Research Institute of Educational Science in Hunan University, Ph.D. in Education, Professor, Doctoral Tutor. Research Field: The Principle of University Teaching and University Psychology. 